\title{
Psychology of Business, Leadership and Communication as a Perspective Scientific Direction in Ukraine and Europe
}

\author{
Natalia Zhyhaylo, Roksolana Karpinska, Nadiya Smolikevych, Marta Kravchyk, Vitalii Lunov.
}

\begin{abstract}
The article deals with highlighting the relevance of the new direction of psychology of business, leadership and communication for the modern labor market. The emphasis has been placed on the fact that the modernization of educational programs promotes Europeanization and improvement of the quality of training so that specialists can operate in intercultural professional environment, and the quality of scientific research leads to constant search in order to ensure the competitiveness of graduates, spread of values and formation of a positive image of the country.

The work presents the educational program "Psychology of Business and Management" for the training of specialists in the psychology of interpersonal and business communication, business counseling, psychological assessment of the staff, personnel management, legal support, organizational behavior and applied ethics, prevention of professional deformations, gender differences in the field of management activities; media psychology, psychology of advertising and public relations (PR) etc.

Methods for successful formation and development of students' personal and professional skills (soft skills) demanded by employers in order to provide their preparedness for being employed by business organizations have been offered; the general socio-psychological basics of success in business have been outlined. A system of values needed for leadership and success has been presented. The concepts of "success" and "successfulness" in the business environment have been considered.
\end{abstract}

Keywords : psychology of business, leadership and communication, business environment, business counseling, values, leadership, success, success, successfulness, criteria, indicators of success.

Revised Manuscript Received on November 15, 2019

* Correspondence Author

Zhyhaylo Natalia Ihorivna, Doctor of Psychology, Professor of Management Department, Ivan Franko National Universiti of Lviv, Lviv, Ukraine

e-mail:nlucyk@ukr.net

Karpinska Roksolana Ivanivna, Ph. D. in Psychology, Department of Psychiatry, Psychology and Sexology, Danylo Halytsky Lviv National Medical University, Lviv, Ukraine

Smolikevych Nadiya Romanivna, $\mathrm{Ph}$. D. in Pedagogy, Docent of Department of Foreign Languages for Natural Sciences, Ivan Franko National University of Lviv, Lviv, Ukraine

Kravchyk Marta Bogdanivna, Ph. D. in Law, Assistant department of Civil Law and Procedure, Ivan Franko National University of Lviv, Lviv, Ukraine

Lunov Vitalii Yevhenovych, Ph. D. in Psychology, Professor, Department of General and Medical Psychology, Bogomolets national medical university, Kyiv, Ukraine

\section{INTRODUCTION}

\section{a. THE RELEVANCE OF THE PROBLEM.}

The modern labor market is filled with cutting-edge technology, innovative ideas, and creative conditions; however, it requires human capital to achieve its goals. In particular, it needs young talented specialists with professional knowledge, communicative, leadership and organizational skills, etc.

It is also characterized by increased competition in the field of higher education among the leading countries that support its openness, accessibility, quality of knowledge, practical application of IT technologies and compliance with the up to date requirements, which are important for its recipients. After all, the modern content of educational programs attracts young people in a certain higher educational establishments, because their priority is to obtain the qualitative, necessary and practical knowledge of the chosen specialty. Therefore, the teaching staff of these institutions need, through lifelong learning, to seek new opportunities to provide quality educational service that would satisfy and attract more and more university entrants.

The new direction is the psychology of business, leadership and communications, which arose at the intersection of a number of disciplines, primarily psychology, sociology, jurisprudence, economics and management, has been designed to contribute to solving topical issues of our time. In particular, the growing demand is for those areas of psychological work, which are associated with the psychological support for the work of various business structures. Today, a lot of organizations (companies, firms, enterprises), involved in the production and sale of goods and services or conducting legal support, need to employ business psychologists in order to improve efficiency, who can understand the modern business specifics, role of the human factor in achieving their goals, and are also able to delegate proper tasks to the managers and staff to overcome difficulties, enhance competitiveness and develop the organization. It is important for the professionals providing psychological support for proper activity of business organizations to see all the diversity, complexity and contradictions of business.

\section{PRESENTATION OF THE MAIN MATERIAL.}

The analysis of the literature on the issue of Europeanization of higher education makes it possible to identify some positive aspects: improvement of educational programs, exchange of scientific and pedagogical staff, that promote modernization and

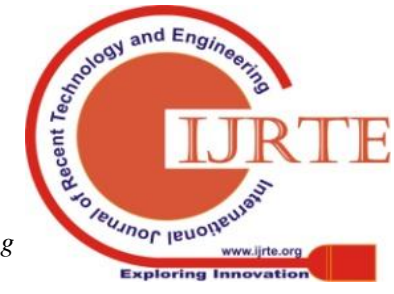


improvement of the quality of training of specialists capable of acting in the intercultural professional environment, flowing additional funds in the economy of the country affecting positively on its growth; improving the quality of scientific research; internationalization leading to a constant search for ensuring competitiveness of graduates; the spread of their own values and formation of a positive image of the country; promotion of cultural expansion.

Globalization processes stimulate higher education systems to be more dynamic in order to meet the changing demands of the international market. Students are willing to obtain a diploma of a more famous university abroad and work for prestigious companies in one of the chosen countries. Cooperation between universities and business is becoming closer, thanks to concluding bi-lateral agreements on undergoing training practice by students while studying, where they have the opportunity to get acquainted with prosperous employers, which is important for their future career, and international organizations have the ability to recruit qualified staff among university students. Collaboration is also being implemented in mutually beneficial research projects (International Student, 2018).

The global labor market is characterized by the selection of highly skilled professionals capable of working in the international environment. Modern knowledge and experience, the required level of the English language command, capability of being adaptable in a multicultural environment, ability to negotiate and run a business with representatives of different cultures are important qualities of a today's specialist [7].

Today, the content of education is changing which is influenced by the rapid pace of globalization, the growth of student and academic mobility, the spread of academic programs and higher educational institutions across borders, the impact of further technology development, and massification that means a wide-spread distribution to a large number of people in the world. University education is at the crossroads of traditions and new opportunities, but changes will be inevitably continuing with challenges and problems becoming more complex and larger every decade, and their solutions will depend on the changes in the educational sphere. We are watching demographic changes, technological breakthroughs, and unstable political and economic conditions in the world that will determine the future of higher education.

In order to realize the goal of modernizing higher education at the Ivan Franko National University of Lviv, the educational program "Psychology of Business and Management" was launched for the training of specialists in the psychology of interpersonal and business communication, business counseling, psychological assessment of the stuff, personnel management, organizational behavior and applied ethics, prevention professional deformations, gender differences in the field of management activities; media psychology, psychology of advertising and PR etc.

Graduates of the specialization "Psychology of Business and Management" may hold positions as a business psychologist, psychologist-trainer, psychologist-consultant; psychologist-psychometrist in the system of entrepreneurial, financial-economic and trade spheres, private sector, coach, consultant in management psychology and communications, PR manager, HR manager, recruiter, creative director, lecturer in business psychology and management.

In order to popularize this direction, we conducted the Career Marathon "Education. Business. Psychology". The uniqueness of this event was in consolidation of universities, academics, business and international experts around the idea of improving the content of education, improving the preparedness of graduates of higher educational institutions to the conditions of the modern labor market, etc. A special emphasis of the marathon has been made on the psychology of business and management as an educational program, extending its content to the direction of "Psychology of Business, Leadership and Communications", and the development of so-called soft skills that are crucial for getting a successful career. The marathon started with a number of trainings of well-known coaches, during which students mastered their skills of speaking, improved communication skills and teamwork, and developed emotional intelligence. The culmination of the event was the International Scientific and Practical Conference "Psychology of Business and Management: Challenges of the Present", in which experts from 10 countries, namely Ukraine, Austria, Germany, Lithuania, Poland, Finland, Georgia, Jordan, Tajikistan, and Canada, and academics from 20 universities took part. Our project "Psychology of Business and Management" also co-operates fruitfully with the Lviv Regional Business Platform, the Regional Council of Entrepreneurs of Lviv Region, the Committee on Education and Personnel Policy of the Lviv Chamber of Commerce and Industry, etc.

\section{METHODOLOGY.}

Research methods. According to the purpose of our research, a complex of theoretical methods has been used, such as: the comparative-historical method, which allowed studying normative documents and laws on education, scientific and educational literature, curricula and curriculum programs; analysis and synthesis -

for analysis of the pedagogical concepts and principles underlying the development of the educational program "Psychology of Business, Leadership and Communications"; induction and deduction methods for collecting, summarizing and interpretation of the research material, identifying the specifics and relevance of the program; analytical and logical methods have been applied to investigate the peculiarities and possibilities of improving the sphere of educational services, the compliance of educational programs with the requirements of the modern global labor market, and also construct causal-consequential relationships; statistical methods, used for checking the obtained information by comparing data from scientific and other sources; the method of systematization and generalization has been used for the formation of judgments and conclusions; empirical methods, among which we can mention questionnaires of students of higher education institutions in order to find out the features, advantages and disadvantages of implementing the educational program "Psychology of Business and Management".

A total of 100 students of higher education institutions from Ukraine and abroad took part in the survey with the help of using modern technologies (for example, e-mail, social networks). The results of the study are presented in Table 1.

Published By: 
The survey has been conducted among boys and girls who are third and fourth year students. $96 \%$ of the respondents answered the question "Do you consider the newest communications to be a perspective one?" positively, but only educational direction - business psychology, leadership and

$4 \%$ did not know the answer or did not know about the existence of this direction (see Table 1).

Results of the study on the implementation of the educational program "Psychology of Business, Leadership and Communications"

\begin{tabular}{|c|c|c|c|c|c|c|c|}
\hline \multirow[t]{2}{*}{ № } & \multirow[t]{2}{*}{ Questions } & \multicolumn{3}{|c|}{$\begin{array}{l}\text { Answers of the respondents } \\
\text { from Ukraine } \\
50 \text { persons }(\%)\end{array}$} & \multicolumn{3}{|c|}{$\begin{array}{l}\text { Answers of respondents from } \\
\text { abroad } \\
50 \text { persons }(\%)\end{array}$} \\
\hline & & Yes & No & $\begin{array}{l}\text { Don't } \\
\text { know }\end{array}$ & Yes & No & $\begin{array}{l}\text { Don't } \\
\text { know }\end{array}$ \\
\hline 1 & $\begin{array}{l}\text { Do you consider the newest educational direction - business } \\
\text { psychology, leadership and communications to be a } \\
\text { perspective one? }\end{array}$ & 96 & 0 & 4 & 98 & 0 & 2 \\
\hline 2 & $\begin{array}{l}\text { Will the educational program "Psychology of Business, } \\
\text { Leadership and Communications" promote to acquire and } \\
\text { develop personal and professional skills (soft skills) of } \\
\text { students studying on the educational program "Psychology of } \\
\text { Business, Leadership and Communications" }\end{array}$ & 92 & 0 & 8 & 94 & 0 & 6 \\
\hline 3 & $\begin{array}{l}\text { Is the program "Psychology of Business, Leadership and } \\
\text { Communications" going to provide students with the } \\
\text { excellent grounding for successful employment and effective } \\
\text { work in a business organization? }\end{array}$ & 92 & 2 & 6 & 92 & 2 & 6 \\
\hline 4 & $\begin{array}{l}\text { Does the program "Psychology of Business, Leadership and } \\
\text { Communications" cover fully the issue on a value system for } \\
\text { leadership and success? }\end{array}$ & 86 & 4 & 10 & 84 & 2 & 14 \\
\hline 5 & $\begin{array}{l}\text { Is a new educational program designed to help specialists in } \\
\text { the psychology of interpersonal and business } \\
\text { communication, business counseling, personnel } \\
\text { management, etc. to create a favorable psychological climate } \\
\text { in the team, corporate ethics on the democratic foundations of } \\
\text { government? }\end{array}$ & 96 & 0 & 4 & 98 & 0 & 2 \\
\hline 6 & $\begin{array}{l}\text { Is the profession of business psychologist in demand on the } \\
\text { global labor market? }\end{array}$ & 92 & 2 & 8 & 94 & 0 & 6 \\
\hline 7 & $\begin{array}{l}\text { Will the completion of the educational program "Psychology } \\
\text { of Business, Leadership and Communications" help students } \\
\text { to become leaders? }\end{array}$ & 90 & 0 & 10 & 92 & 0 & 8 \\
\hline
\end{tabular}

The prospective of further development of this direction is the creation of all the necessary conditions for the successful formation and development of students' personal and professional skills (soft skills) demanded by employers to prepare for employment in business organizations. The basis of the professional competence of future professionals is communicative, organizational and leadership abilities. Soft skills also comprise situational awareness, adaptability or flexibility, the ability to be diplomatic and tactful, and so on. So, soft skills cover good manners and personality traits needed to interact with other people in order to form partnerships with them. Soft Skills are used in any industry, every profession, every kind of activity and interpersonal cooperation. In order to develop so-called "soft skills" of future specialists, their training should be started purposefully, and from the first year of studying at higher educational institutions.

In the context of "business psychology, leadership and communication" every businessman, first- year student or other person is interested in the questions: "How to become a leader?" and "How to succeed in business?".

Leadership is the most important factor of success. The leader's behavior is characterized by the following main features, as: initiative in interpersonal interactions;

adaptability to the general momentary mood; lack of the strict planning, love for improvisation; sensitivity to the group members' problems, special attention to the weak; demonstration of dominant behavior, desire and fair for power; vision of views and ideas; openness to people; perseverance and persistence at any work.

Leadership comprises the development of vision, planning, decision-making, motivation, organization, development, delegating the power, and leading people to achieve specific goals. Leadership is a kind of power, the specifics of which are the direction from the top down, as well as the fact that its owner is not the majority, but one person or a group of people. Leadership is a managerial status, social position associated with decision-making, a position of a leader. Such interpretation of leadership is proposed from a structural and functional approach, which implies consideration of society as a complex, hierarchically organized system of social positions and roles. Leadership is a natural social and psychological process in a group based on the influence of a person's own authority on the behavior of group members. The leader is the one who leads; the first one who goes ahead always wins; leads to success. 
Psychological researches [1-9] allow identifying existing ideas in society concerning success and successful people, desirable images of the ideal of success and prototypes of a successful personality. Thus, according to the modern data, an ideal successful person is purposeful, sociable, intelligent, well-being and responsible. Description of the ideal successful person focuses on his or her personal characteristics, methods to achieve success, but not on concrete results of activity and other manifestations of success. The image of a really successful person includes main social benefits of mankind, as: wealth, a prosperous family, gaining career growth, ability to achieve goals, a prestigious job a high social status, children, the status of a boss, own business, etc.

Modern scholars [2; 3; 4; 5] present a typology of ideas about success in accordance with a type of responsibility; in particular, they distinguish such types, as optimally responsible, executive, situational, selfish and functional.

Achievement motivation is an important factor in business and career success. The motivation for the achievement is seen to be the driving force which promotes getting a success. This type of motivation refers to one of the main psychogenic needs, that is, the needs associated with the most essential aspects of human life, without which it is impossible to fully develop human beings. Achievement motivation is the key to success.

Own experience of achievements. Real success is the most reliable reason for believing in yourself and being able to protect yourself from failures. In addition, when the basis for a sense of self-efficacy comprises the actual actions and achievements of a person, it is usually summarized in a number of similar activities. The achieved success increases at least the sense of self-efficacy if the task was easy, not difficult.

The experience of other people (indirect experience) is also an important source of self-efficacy. Self-efficacy increases when people watch as others succeed in solving complex tasks. At the same time, they are convinced that if other persons can do this, they can also improve their performance.

"Strong will and self-discipline; belief in town strength and dream, according to the prominent economist Bohdan Havrylyshyn, will help achieve even inaccessible, at first glance, goals." [2].

Also, in Bohdan Havrylyshyn's opinion, psychological characteristics of successful individuals in the business include creativity, that means to be creative you need to be a little childish, and have childhood dreams and fantasies; dream: it is necessary to start with a dream, but not with a business plan; to go beyond the ordinary is to look at the situation and problems from another, unusual point of view; Curiosity is to learn constantly, to learn something new, to work on self-improvement in all spheres of life, to provide the basis for a long-term future; success, as effective person learns all life; strong will and self-discipline, that means you need to learn how to do what you have to do, what is useful to do, rather than just what you want to do; belief, because it is always important to believe in your strength and dream, and continue to dream about the great things, even unreal to attain at first glance [2].

The writer Elizabeth Gilbert defines notions "success, failure and drive to continue creating" saying that: "If once a great failure or great success break your relationship with your roots, then your duty is to find the way to your roots. The only way to restore this connection is to start working hard and do your job diligently and faithfully, with respect and honor. It does not matter what exactly you do, let your love guide you. Your roots are what you direct your energy to with such impressive devotion that the results are not very important" [2].

Summarizing the results of researches of domestic and foreign scientists, we present a comparative description of psychological characteristics of successful and unsuccessful individuals in business (see Table2).

Psychological features of successful and unsuccessful persons

\begin{tabular}{|c|c|}
\hline Psychological features of successful persons & Psychological features of unsuccessful persons \\
\hline Read everyday & Watch TV everyday \\
\hline Praise & Criticize \\
\hline Use changes & Afraid of changes \\
\hline Forgive others & Take offence \\
\hline Discuss ideas & Discuss people \\
\hline Learn all life & Blame others for your failures \\
\hline Take responsibility for your own mistakes & believe that other people are guilty of your own failures \\
\hline Be able to thank & Do not set goals \\
\hline Set goals and plan the life &
\end{tabular}

Among qualities of a successful person we can point out the power of desires, a powerful internal impulse, justified optimism, openness to real facts, contemporary competence, dedication, charisma, willingness to risk, sense of change, responsibility and morality, high spirituality, clear thinking and no alternative, rationality in relation to money, self-realization in business, democratic principles and modesty, uniqueness etc.

\section{CONCLUSIONS.}

We have justified the relevance of the newest direction of psychology of business, leadership and communication for the modern labor market. The emphasis has been placed on the fact that the modernization of educational programs promotes Europeanization and the improvement of the quality of training so that specialists can operate in an intercultural professional environment, and the quality of scientific research

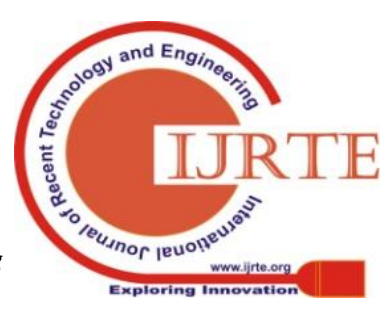


leads to constant search in order to ensure the competitiveness of graduates, spread of values and formation of a positive image of the country. The educational program "Psychology of Business and Management" has been presented for training specialists in the psychology of interpersonal and business communication, business counseling, psychological assessment of the staff, personnel management, organizational behavior and applied ethics, prevention of professional deformations, gender differences in the field of management activities; media psychology, psychology of advertising and PR etc. Methods of successful formation and development of students' personal and professional skills (soft skills), which are demanded by employers, for their being prepared to be employed in business organizations have been offered; the general socio-psychological basics of success in business have been revealed. A system of the values needed for leadership and success has been developed. The concepts of "success" and "successfulness" in the business environment in the business environment have been outlined.

\section{REFERENCES}

1. Variy M.Y. Psychology of personality: a handbook. - Kyiv: Center for Educational Literature, 2008. - 592 p.

2. Zhyhailo N.I., Kokhan M.O., Danylevych N.M. Psychology of business. A handbook. - Lviv: Publishing Center of Ivan Franko National University of Lviv, 2019. - 308 p.

3. Zhyhailo N. I. Psychology of the spiritual formation of the personality of the future specialist: Monograph. - Lviv: Publishing Center of Ivan Franko National University of Lviv, 2008. - 336 p.

4. Maksymenko S.D. Psychology of Personality: a textbook. - Kyiv: KMM, 2007. - 296 p.

5. Moskalets V.P. Psychology of Religion: a manual. - Kyiv: Akadem. Press, 2004. - 240 p.

6. Savchyn M.V. Spiritual Human Potential: Monograph / M.V. Savchyn. - Ivano-Frankivsk, 2001. - 202 c.

7. Smolikevych N.R. The organizational and pedagogical provision of foreign students' adaptation in US universities: author's abstract of thesis for obtaining a scientific degree of Candidate of Pedagogical Sciences. - Lviv: LLC "Western Ukrainian Consulting Center" Press, 2018. - 24 p.

8. Yatsura V.V., Khoronjyi A.H, Zhyhailo N.I. Psychology of the manager: a handbook. - Lviv: Publishing Center of Ivan Franko National University of Lviv, 2012. - 256 p.

\section{AUTHORS PROFILE}

Zhyhaylo Natalia Ihorivna, Doctor of Psychology, Professor of Management Department, Ivan Franko National Universiti of Lviv, Lviv, Ukraine

e-mail:nlucyk@ukr.net

Karpinska Roksolana Ivanivna, $\mathrm{Ph}$. D. in Psychology, Department of Psychiatry, Psychology and Sexology, Danylo Halytsky Lviv National Medical University, Lviv, Ukraine

Smolikevych Nadiya Romanivna, Ph. D. in Pedagogy, Docent of Department of Foreign Languages for Natural Sciences, Ivan Franko National University of Lviv, Lviv, Ukraine

Kravchyk Marta Bogdanivna, Ph. D. in Law, Assistant department of Civil Law and Procedure, Ivan Franko National University of Lviv, Lviv, Ukraine

Lunov Vitalii Yevhenovych, Ph. D. in Psychology, Professor, Department of General and Medical Psychology, Bogomolets national medical university, Kyiv, Ukraine 